\title{
Analisa Manfaat Implementasi Electronic Customs Clearance System (ECCS) di Chevron Indonesia Company Balikpapan dengan Metode Information Economics
}

\author{
Ajeng Vrika Nerissa Bhisma, Flourensia Sapty Rahayu \\ PT. Indotek Perkasa Jaya \\ Jl. Mulawarman No. 177, Sepinggan, Balikpapan 76115, Indonesia \\ Email: ajeng.vrika@indotek-bpn.com \\ Program Studi Teknik Informatika, Universitas Atma Jaya Yogyakarta \\ Jl. Babarsari No. 43, Yogyakarta 55281, Indonesia \\ E-mail: sapty@staff.uajy.ac.id
}

\begin{abstract}
Benefit Analysis of Electronic Customs Clearance System (ECCS) Implementation in Chevron Indonesia Company Balikpapan using Information Economics Method. Companies continue invest their money in Information Technology in order to get values for their business. The investments are expected to produce values that worth with the cost spent. Chevron Indonesia Company, a global natural gas and oil exploration company which one of its subsidiary is in Balikpapan has also been use Information Technology to run their business. One of the applications they have is Electronic Customs Clearance System (ECCS) that automate the export import processes. In this paper we will analyze the benefits of ECCS implementation to the company with financial approach of Information Economics methodology.
\end{abstract}

Keywords: value, benefits, Electronic Customs Clearance System, Information Economics

\begin{abstract}
Abstrak. Perusahaan terus menginvestasikan uang mereka dalam Teknologi Informasi dalam rangka untuk mendapatkan nilai untuk bisnis mereka. Investasi diharapkan untuk menghasilkan manfaat yang senilai dengan biaya yang dihabiskan. Chevron Perusahaan Indonesia, gas alam global dan perusahaan minyak eksplorasi yang salah satu anak perusahaan adalah di Balikpapan juga telah menggunakan Informasi Teknologi untuk menjalankan bisnis mereka. Salah satu aplikasi yang mereka miliki adalah Sistem Elektronik Customs Clearance (ECCs) yang mengotomatisasi proses ekspor impor. Dalam tulisan ini kita akan menganalisis manfaat pelaksanaan ECCs kepada perusahaan dengan pendekatan keuangan metodologi Informasi Ekonomi.
\end{abstract}

Kata Kunci: nilai, manfaat, Elektronik Sistem Bea Cukai Clearance, Ekonomi Informasi

\section{Pendahuluan}

\subsection{Latar Belakang}

Chevron Indonesia Company (CICo) adalah salah satu perusahaan eksplorasi dan produksi gas alam dan minyak mentah terkemuka di dunia yang salah satu cabangnya berada di Balikpapan. Perkembangan teknologi informasi (TI) yang pesat turut membuat CICo mengandalkan kemampuan TI dalam operasional perusahaannya. 
Salah satu proses dalam siklus hidup perusahaan adalah pengadaan barang. Jika barang yang dibutuhkan perlu diadakan dari luar negeri, pembelian barang dilakukan secara impor. Proses impor tak luput dari prosedur yang rumit karena tak hanya menyangkut hubungan internal CICo saja tetapi juga berhubungan dengan pihak eksternal, seperti Bea Cukai, Ditjen Migas, dll. Pada awalnya semua proses dilakukan secara manual sehingga seringkali kesalahan terjadi karena berbagai faktor. Masalah administrasi seperti keterlambatan Masterlist, perbedaan deskripsi barang, ketidakcocokan antara dokumen pre-alert dan Masterlist merupakan contoh permasalahan yang sering dihadapi. Menurut kebijakan yang ada setiap pelanggaran akan dikenakan sanksi berupa denda yang tertera pada Surat Pemberitahuan Kekurangan Pembayaran Bea Masuk (SPKPBM). Denda ini akan berdampak pada penambahan pengeluaran yang harus dikeluarkan oleh perusahaan.

Oleh karena itu salah satu bentuk upaya perusahaan untuk membenahi proses pengadaan barang ini adalah dengan menerapkan Electronic Customs Clearance System (ECCS). Sistem ini digunakan oleh Supply Chain Management Department untuk divisi Procurement (Custom \& Traffic Group) dan pihak yang berkaitan dengan operasional departemen tersebut.

\subsection{Tujuan Penelitian}

Tujuan dari penelitian ini adalah melakukan analisa terhadap implementasi aplikasi ECCS serta manfaat-manfaat yang didapatkan dari implementasi aplikasi tersebut dengan menggunakan metode Information Economics.

\subsection{Batasan Masalah}

(1) Sumber-sumber yang terkait dan informasi yang dihasilkan diperoleh dari pihak internal CICo Balikpapan, khususnya user dari ECCS yaitu Custom \& Traffic Group pada Supply Chain Management Procurement Department. (2) Pendekatan yang digunakan dalam melakukan analisa manfaat hanya menggunakan pendekatan finansial yang mengkaji manfaat yang sifatnya tangible dan quasi tangible saja dari metode Information Economics. Untuk analisa manfaat intangible secara non finansial diluar lingkup penelitian ini. (3) Penilaian proyek yang dilakukan hanya sampai pada penghitungan ROI, tidak sampai pada proses scoring. (4) Hasil analisa serta penarikan kesimpulan dari penelitian ini adalah dari dan untuk CICo Kalimantan.

\section{Tinjauan Pustaka}

\subsection{Manfaat Investasi TI}

Sampai sejauh ini dikenal ada 2 tipe dari manfaat TI yang umum dikenal atau digunakan, yaitu manfaat tangible dan manfaat quasi. Diantara kedua manfaat tersebut dikenal manfaat quasi tangible. Kebutuhan untuk penilaian dan pengukuran manfaat TI yang terus bertambah telah menghasilkan tipe manfaat TI yang lebih detil. Ranti (2006) menyimpulkan ada 4 tipe manfaat yang disebut IT Benefit Matrix: (1) Easy-to-Quantify Tangible (EQT) atau Hard Benefit, yaitu manfaat-manfaat TI yang secara langsung mempengaruhi profitabilitas perusahaan dan efeknya dapat diukur secara langsung dan obyektif. Contoh manfaat: pengurangan biaya dan peningkatan pendapatan. (2) Hard-to-Quantify Tangible (HQT), yaitu manfaat-manfaat TI yang secara langsung mempengaruhi profitabilitas perusahaan, tetapi efek tepatnya tidak dapat diukur secara langsung. Contoh manfaat: informasi yang lebih baik dan peningkatan keamanan perusahaan. (3) Easy-to-Quantify Intangible (EQI), yaitu manfaatmanfaat TI yang dapat diukur tetapi efeknya tidak berpengaruh secara langsung dan perlu bagi profitabilitas perusahaan. Contoh manfaat: peningkatan kepuasan pelanggan dan peningkatan kepuasan staf. (4) Hard-to-Quantify Intangible (HQI) atau Strategic/Soft Benefit, yaitu manfaat- 
manfaat TI yang tidak dan efeknya tidak tidak berpengaruh secara langsung dan perlu bagi profitabilitas perusahaan. Contoh manfaat: perbaikan reaksi pasar dan peningkatan citra perusahaan. HQT dan EQI dapat dikatakan sebagai turunan dari quasi-quasi.

\subsection{Metode Information Economics (IE)}

Perkembangan TI turut memberikan tekanan pada perusahaan dalam hal pengambilan keputusan untuk mengalokasikan sumber daya, termasuk dana untuk TI, apakah sebanding antara sumber daya/investasi yang telah dikeluarkan dengan manfaat bagi bisnis yang diperoleh dari TI tersebut. Parker, dkk (1988) mengembangkan sebuah metode penilaian kelayakan proyek TI yang dinamakan Information Economics (IE). IE memiliki kelebihan dibandingkan dengan metode penilaian yang lain yaitu IE adalah satu-satunya metode yang memiliki alat bantu yang spesifik untuk menangani ketidakpastian, ketidaknyataan, dan ambiguitas yang sering ditemui dalam investasi TI. Metodologi IE dapat digunakan untuk membantu bisnis dan manajer-manajer TI untuk mengukur dan memprioritaskan proyek-proyek TI berdasar pada nilai kembaliannya.

Beberapa konsep dasar yang dikembangkan dalam metode ini adalah konsep benefit dan cost. Konsep benefit diperluas dengan mengembangkan konsep value yang lebih luas berdasar pada efek-efek yang dihasilkan dari investasi TI pada unjuk kerja bisnis di perusahaan. Pengurangan biaya dan penghasilan keuntungan adalah contoh-contoh dari manfaat tradisional yang merupakan komponen dari value, tetapi begitu juga dengan keunggulan kompetitif dan peningkatan penguasaan pasar. Konsep cost juga dikembangkan dengan menyertakan dampakdampak negatif dari investasi TI pada perusahaan. Sebagai contoh, TI yang baru membawa kegelisahan/kebingunagan karena kurangnya pelatihan dan persiapan dalam organisasi. Meskipun tidak secara diskret diidentifikasi sebagai bagian dari biaya akuisisi dari software, ini adalah masalah nyata yang dapat mempengaruhi unjuk kerja organisasi untuk beberapa waktu.

Metode IE menggunakan dua pendekatan dalam melakukan analisa terhadap manfaatmanfaat TI. Pendekatan pertama adalah pendekatan finansial yang diterapkan untuk manfaatmanfaat yang sifatnya tangible dan quasi. Pendekatan kedua adalah pendekatan non finansial yang diterapkan untuk manfaat-manfaat yang sifatnya quasi. Teknik yang digunakan untuk menganalisa manfaat tangible menggunakan metode Traditional Cost Benefit Analysis dalam bentuk simple ROI. Sedangkan untuk manfaat quasi menggunakan teknik-teknik: (1) Value Linking: digunakan untuk mengevaluasi manfaat yang merepresentasikan ripple effect dari peningkatan suatu fungsi atau proses antar bagian akibat dari implementasi TI yang tidak tergantung dengan waktu, misal pendapatan yang diperoleh akibat berkurang atau hilangya kesalahan proses billing. (2) Value Acceleration: digunakan untuk mengevaluasi manfaat yang merepresentasikan ripple effect dari peningkatan suatu fungsi atau proses antar bagian akibat dari implementasi TI yang tergantung dengan waktu, misal pendapatan yang diperoleh karena semakin cepatnya proses penyiapan invoice. (3) Value Restructuring: digunakan untuk mengevaluasi manfaat yang berhubungan dengan adanya restrukturisasi suatu tugas atau proses bisnis sebagai akibat dari penerapan TI sehingga dapat mengurangi non productive time. (4) Innovation Valuation: digunakan untuk mengevaluasi manfaat yang diperoleh terkait adanya fungsi baru dalam domain bisnis dikarenakan cara perusahaan berbisnis berubah sebagai akibat dari penerapan TI.

Analisa terhadap manfaat quasi menggunakan dua penilaian yaitu: (1) Business Domain: Komponen-komponen penilaian dari domain bisnis antara lain Strategic Match, Competitive Advantage, Management Information Support, dan Competitive Response. (2) Technology Domain: Komponen-komponen penilaian dari domain ini antara lain Strategic IS Architecture, Defitional Uncertainty, Technical Uncertainty, dan Infrastructure Risk.

Kategori manfaat tangible dan quasi tangible menggunakan pendekatan financial enhanced ROI, dimana hasil penilaiannya menghasilkan suatu nilai moneter dan skor angka sedangkan kategori manfaat quasi menggunakan pendekatan non finansial, dimana hasil 
penilaiannya adalah sebuah skor angka. Pada kategori ke-3 ini, skor berkisar dari 0-5 Dengan demikian, nilai proyek SI/TI diukur dengan formula berikut ini (Parker, 1988):

\section{Rumus 1. Skor Proyek}

Skor Proyek = Enhanched ROI + bobot bidang bisnis + bobot bidang teknologi

\section{Rumus 2. Enhanced ROI}

Enhanced $R O I=$ Traditional $R O I+$ value linking + value acceleration + value restructuring + innovation valuation

\section{Analisis Permasalahan}

\subsection{Profil Aplikasi Electronic Customs Clearance System (ECCS)}

ECCS merupakan sistem elektronik untuk menangani dokumen/administrasi menyangkut kegiatan impor barang yang dilakukan oleh CICo. Pihak eksternal yang terkait dengan proses ini antara lain negara luar, Bea Cukai, Ditjen Migas, dll. Semula proses Custom Clearance dilakukan secara manual dengan menggunakan data-data Excel yang disimpan di server, kemudian untuk pertukaran dan pengiriman data menggunakan e-mail. Namun proses manual tersebut menimbulkan human error yang cukup tinggi dan menyebabkan proses procurement pun terhambat.

Semua aplikasi pada Chevron Corporation merujuk pada suatu aplikasi besar/induk bernama JDE (aplikasi ERP), namun tidak terintegrasi secara langsung. JDE berinteraksi dengan IBU (IndoAsia Bussiness Unit) Data Warehouse yang merupakan basis data Chevron Corporation. Gambar 1 menunjukkan relasi antara JDE dan ECCS.

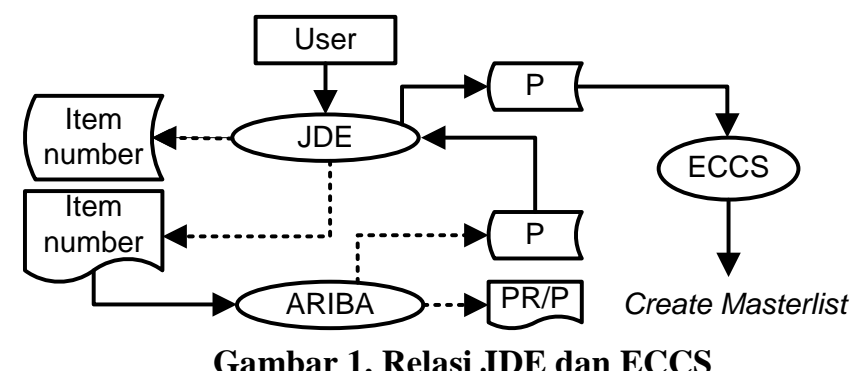

User mengakses JDE untuk membuat/mendaftarkan item number agar Purchase Requisition (PR) bisa dibuat di ARIBA. ARIBA merupakan nama aplikasi yang digunakan oleh tim Procurement (Buyer) yang menangani hal yang berkaitan dengan permintaan pembelian barang hingga kesepakatan pembelian barang. Dalam kondisi lain, Purchase Requisition (PR) bisa dilakukan melalui JDE. Ada 2 jenis Purchase Requisition (PR) pada JDE, yaitu MPR dan JDEPR. Dari JDE, Purchase Requisition (PR) tersebut akan tergenerate langsung ke ARIBA. Di ARIBA, grup Buyer akan membuat Purchase Requisition (PR), Requisition For Quotation (RFQ) dan Purchase Order (PO). Karena sistem terintegrasi, data Purchase Order (PO) yang di ARIBA secara otomatis juga tersimpan di JDE. Disinilah saat ECCS berinteraksi dengan JDE, yaitu untuk mengambil data Purchase Order (PO). Berdasarkan Purchase Order (PO) tersebut, Masterlist dibuat di ECCS.

Gambar 2 mengilustrasikan informasi utama yang dikelola oleh ECCS, yaitu Masterlist, Invoice, Import Status, Service Company (SC) Masterlist, Monitoring Goods Group, dan Recognition \& Notification Correspondence. 


\section{e-Customs Clearance System}

Business Features

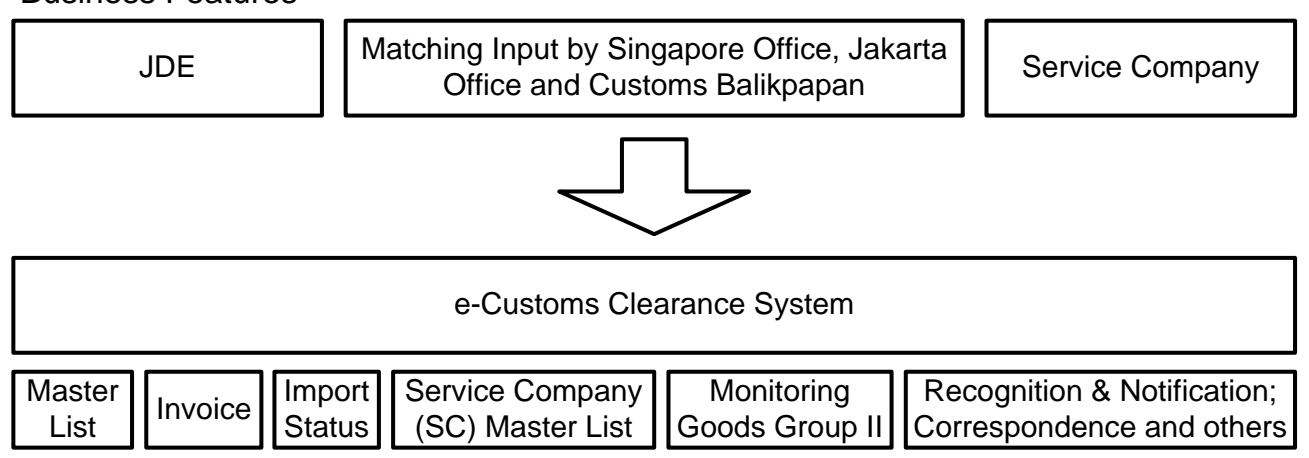

\section{Gambar 2. Fitur Bisnis ECCS}

\subsection{Identifikasi dan Analisa Manfaat ECCS}

Hasil identifikasi manfaat tangible dan quasi tangible dari ECCS dapat dilihat di tabel 1 , tabel 2 , tabel 3 , tabel 4 , tabel 5 , tabel 6 , tabel 7 dan tabel 8 .

Tabel 1. Manfaat Tangible - Mengurangi Biaya Telekomunikasi

\begin{tabular}{|c|c|}
\hline Manfaat & Mengurangi biaya telekomunikasi \\
\hline $\begin{array}{l}\text { Kondisi } \\
\text { Sebelum }\end{array}$ & $\begin{array}{l}\text { Penggunaan telepon baik lokal maupun interlokal mencapai rata-rata } 50 \text { kali / } \\
\text { minggu. Rata-rata percakapan selama } 2 \text { menit. Untuk tarif telepon lokal maupun } \\
\text { interlokal sama karena Jawa-Kalimantan merupakan cluster yang sama, yaitu Rp } \\
125,-/ \text { menit. Tarif email sebesar Rp } 2.100,-/ \text { bulan. } \\
\text { Perhitungan : } \\
\text { (Tarif telepon } * \text { Lama bicara * Frekuensi telepon dalam setahun) }+ \text { tarif email } \\
\text { setahun }=(125 * 2 * 2400)+25200=\mathrm{Rp} 625.200,-\end{array}$ \\
\hline $\begin{array}{l}\text { Kondisi } \\
\text { Sesudah }\end{array}$ & $\begin{array}{l}\text { Penggunaan telepon dalam seminggu baik lokal maupun interlokal mencapai } 15 \text { kali. } \\
\text { Rata-rata percakapan selama } 2 \text { menit. Untuk tarif telepon lokal maupun interlokal } \\
\text { sama karena Jawa-Kalimantan merupakan cluster yang sama, yaitu Rp } 125,-/ \text { menit. } \\
\text { Tarif email sebesar Rp } 2.100,-/ \text { bulan. } \\
\text { Perhitungan : } \\
\text { (Tarif telepon } * \text { Lama bicara } * \text { Frekuensi telepon dalam setahun })+ \text { tarif email } \\
\text { setahun }=(125 * 2 * 720)+25200=\mathrm{Rp} 205.200,-\end{array}$ \\
\hline Penghematan & Rp 625.200 - Rp $205.200=\operatorname{Rp} 420.000$ \\
\hline
\end{tabular}

Tabel 2. Manfaat Tangible - Mengurangi Biaya Pengiriman Dokumen

\begin{tabular}{ll}
\hline Manfaat & Mengurangi biaya pengiriman dokumen \\
\hline Kondisi & Pada approval flow, pengiriman lokal mencapai 3 kali dan interlokal mencapai 8 kali \\
Sebelum & dengan tarif lokal sebesar Rp 5.000,- dan interlokal sebesar Rp 17.000,- untuk semua \\
& rute. Rata-rata kuantiti Masterlist yang dihasilkan dalam setahun sebanyak 24 buah. \\
& Perhitungan : \\
& (tarif interlokal * kuantiti Masterlist $*$ frekuensi pengiriman $)+($ tarif local * kuantiti \\
& Masterlist $*$ frekuensi pengiriman $)=(17000 * 24 * 8)+(5000 * 24 * 3)=$ Rp \\
& 3.624.000,- \\
\hline Kondisi & Pada approval flow, pengiriman lokal mencapai 3 kali dan interlokal mencapai 2 kali \\
Sesudah & dengan tarif lokal sebesar Rp 5.000,- dan interlokal sebesar Rp 17.000,- untuk semua \\
& rute. Rata-rata kuantiti Masterlist yang dihasilkan dalam setahun sebanyak 19 buah. \\
& Perhitungan : \\
& (tarif interlokal $*$ kuantiti Masterlist $*$ frekuensi pengiriman $)+($ tarif local $*$ kuantiti \\
& Masterlist $*$ frekuensi pengiriman $)=(17000 * 19 * 2)+(5000 * 19 * 3)=$ Rp \\
& $931.000,-$ \\
\hline Penghematan & Rp 3.624.000 - Rp 931.000 = Rp 2.693.000,- \\
\hline
\end{tabular}


Tabel 3. Manfaat Tangible - Mengurangi Biaya Cetak Dokumen

\begin{tabular}{|c|c|}
\hline Manfaat & Mengurangi biaya cetak dokumen \\
\hline Kondisi & Perkiraan untuk harga 1 rim kertas sebesar $\mathrm{Rp} 40.000,-$, harga catridge sebesar Rp \\
\hline Sebelum & $\begin{array}{l}250.000,- \text { Dengan frekuensi penggunaan dalam setahun sebanyak } 24 \text { rim untuk } \\
\text { kertas dan } 3 \text { catridge. Biaya sewa dan pemeliharaan printer selama setahun sebesar } \\
\text { Rp } 400.000,- \\
\text { Perhitungan: } \\
\text { (harga rim kertas } * \text { jumlah penggunaan kertas })+(\text { harga catridge } * \text { jumlah } \\
\text { penggunaan catridge })+ \text { biaya maintenance printer }=(40000 * 24)+(250000 * 3)+ \\
400000=\text { Rp. } 2.110 .000,-\end{array}$ \\
\hline Kon & Perkiraan untuk harga 1 rim kertas sebesar $\mathrm{Rp} 40.000,-$, harga catridge sebesar $\mathrm{Rp}$ \\
\hline & $\begin{array}{l}250.000,- \text { Dengan frekuensi penggunaan dalam setahun sebanyak } 12 \text { rim untuk } \\
\text { kertas dan } 1 \text { catridge. Biaya sewa dan pemeliharaan printer selama setahun sebesar } \\
\text { Rp } 400.000,- \\
\text { Perhitungan: } \\
\text { (harga rim kertas } * \text { jumlah penggunaan kertas })+(\text { harga catridge } * \text { jumlah } \\
\text { penggunaan catridge })+ \text { biaya maintenance printer }=(40000 * 12)+250000+ \\
400000=\mathrm{Rp} 1.130 .000,-\end{array}$ \\
\hline 19 & $00-\operatorname{Rp} 1.130 .000=\operatorname{Rp} 980.000,-$ \\
\hline
\end{tabular}

Tabel 4. Manfaat Tangible - Mengurangi Biaya Denda Prosedur

\begin{tabular}{|c|c|}
\hline Manfaat & Mengurangi biaya denda prosedur \\
\hline Kondisi & Rata-rata biaya denda SPKPBM yang terjadi selama masa pre-implementasi \\
\hline \multirow[t]{5}{*}{ Sebelum } & Perhitungan : \\
\hline & (Total Paid SPKPBM 2000 + Total Paid SPKPBM 2001 + Total Paid SPKPBM 2002 \\
\hline & + Total Paid SPKPBM 2003 + Total Paid SPKPBM 2004) $=(0+0$ + $1074023867+$ \\
\hline & $146082+3024061175)=4098231124 / 3$ \\
\hline & Rata-rata per tahun $=\mathrm{Rp} 1.366 .077 .041,-$ \\
\hline Kondisi & Biaya denda SPKPBM yang terjadi selama masa pasca implementasi \\
\hline \multirow[t]{3}{*}{ Sesudah } & Perhitungan : \\
\hline & (Total Paid SPKPBM 2005 + Total Paid SPKPBM 2006 + Total Paid SPKPBM 2007 \\
\hline & $\begin{array}{l}+ \text { Total Paid SPKPBM } 2008+\text { Total Paid SPKPBM 2009 })=(58832548+0+0+0+ \\
0)=\text { Rp.58.832.548,- }\end{array}$ \\
\hline Penghematan & Tahun $1=1366077041-58832548=\operatorname{Rp} 1.307 .244 .493,-$ \\
\hline & Tahun $2=1366077041-0=\operatorname{Rp} 1.366 .077 .041,-$ \\
\hline & Tahun $3=1366077041-0=\operatorname{Rp} 1.366 .077 .041,-$ \\
\hline & Tahun $4=1366077041-0=\operatorname{Rp} 1.366 .077 .041,-$ \\
\hline & Tahun $5=1366077041-0=\operatorname{Rp} 1.366 .077 .041,-$ \\
\hline
\end{tabular}

Manfaat Quasi Tangible. Manfaat-manfaat quasi yang diidentifkasi dapat dievaluasi menggunakan Value Linking, Value Acceleration, dan Value Restructuring. Tidak ada manfaat teridentifikasi yang masuk pada kelompok Innovation Valuation.

\section{Analisa Value Linking}

Tabel 5. Manfaat Quasi - Meningkatkan Kapasitas Bisnis

\begin{tabular}{ll}
\hline Manfaat & Meningkatkan kapasitas bisnis \\
\hline Bagan Alur & peningkatan kapasitas bisnis $\rightarrow$ peningkatan time saving dalam penanganan \\
Penelusuran & pekerjaan $\rightarrow$ mempercepat proses impor barang dan Custom Clearance $\rightarrow$ \\
Manfaat & pengurangan durasi dalam penanganan pekerjaan $\rightarrow$ pengurangan tenaga kerja yang \\
& menangani $\rightarrow$ penghematan atas biaya gaji tenaga kerja \\
\hline Kondisi & Kapasitas bisnis belum tercapai karena keterbatasan sumber daya. Dalam \\
Sebelum & menyelesaikan proses pengadaan barang ini masih membutuhkan waktu yang lama. \\
& Pada masa ini (5 tahun) jumlah rata-rata durasi pengerjaan sebesar 852.9 hari, dengan \\
& rata-rata tenaga kerja sebanyak 7 orang \\
\hline Kondisi & Peningkatan kapasitas bisnis bisa tercapai karena kuantitas, kualitas pekerjaan yang \\
\hline
\end{tabular}




\begin{tabular}{ll}
\hline Sesudah & meningkat dan dapat selesai dalam waktu yang lebih singkat. Pada masa ini (5 tahun) \\
& jumlah rata-rata durasi pengerjaan sebesar 398.55 hari, dengan rata-rata tenaga kerja \\
& sebanyak 3 orang \\
\hline Penghematan & $\begin{array}{l}\text { Berhubung karena penelusuran ini akhirnya mengacu pada percepatan proses maka } \\
\text { perhitungan penghematan tenaga kerja yang dihasilkan dari peningkatan kapasitas }\end{array}$ \\
& bisnis ini akan mengacu pada perhitungan Value Acceleration pada manfaat \\
& "mempercepat proses Shipping Documents".
\end{tabular}

Tabel 6. Manfaat Quasi - Meningkatkan Kualitas Administrasi

\begin{tabular}{|c|c|}
\hline Manfaat & Meningkatkan kualitas administrasi \\
\hline $\begin{array}{l}\text { Bagan Alur } \\
\text { Penelusuran } \\
\text { Manfaat }\end{array}$ & $\begin{array}{l}\text { Peningkatan kualitas administrasi } \rightarrow \text { Keakuratan meningkat } \rightarrow \text { risiko berkurang } \rightarrow \\
\text { penghematan atas denda risiko kesalahan data }\end{array}$ \\
\hline $\begin{array}{l}\text { Kondisi } \\
\text { Sebelum }\end{array}$ & $\begin{array}{l}\text { Keakuratan berkaitan dengan pengurangan akan risiko pekerjaan seperti kesalahan } \\
\text { data, kesalahan hitung, dll. } \\
\text { Perhitungan : } \\
\text { (SPKPBM Value } 2000+\text { Import Duties) + (SPKPBM Value } 2001+\text { Import Duties })+ \\
\text { (SPKPBM Value } 2002+\text { Import Duties) + (SPKPBM Value } 2003+\text { Import Duties })+ \\
\text { (SPKPBM Value } 2004+\text { Import Duties) }\end{array}$ \\
\hline & $\begin{array}{l}=0+0+((31011405+328975+2335195+17302046+13503085+9910675+ \\
11566587)+0)+((10537+135545)+0)+0=\operatorname{Rp} 86.104 .050,- \\
\text { Rata-rata per tahun }=\operatorname{Rp} 86.104 .050 / 2\end{array}$ \\
\hline $\begin{array}{l}\text { Kondisi } \\
\text { Sesudah }\end{array}$ & $\begin{array}{l}\text { Keakuratan pelaporan sudah meliputi keakuratan data dan informasi yang terkandung } \\
\text { didalamnya sehingga tidak ditemukan lagi pelanggaran dan denda. } \\
\text { Perhitungan : - }\end{array}$ \\
\hline Penghematan & Rp 43.052.025,-- \\
\hline
\end{tabular}

Tabel 7. Manfaat Quasi - Mengurangi Resiko Keterlambatan dan Jatuh Tempo

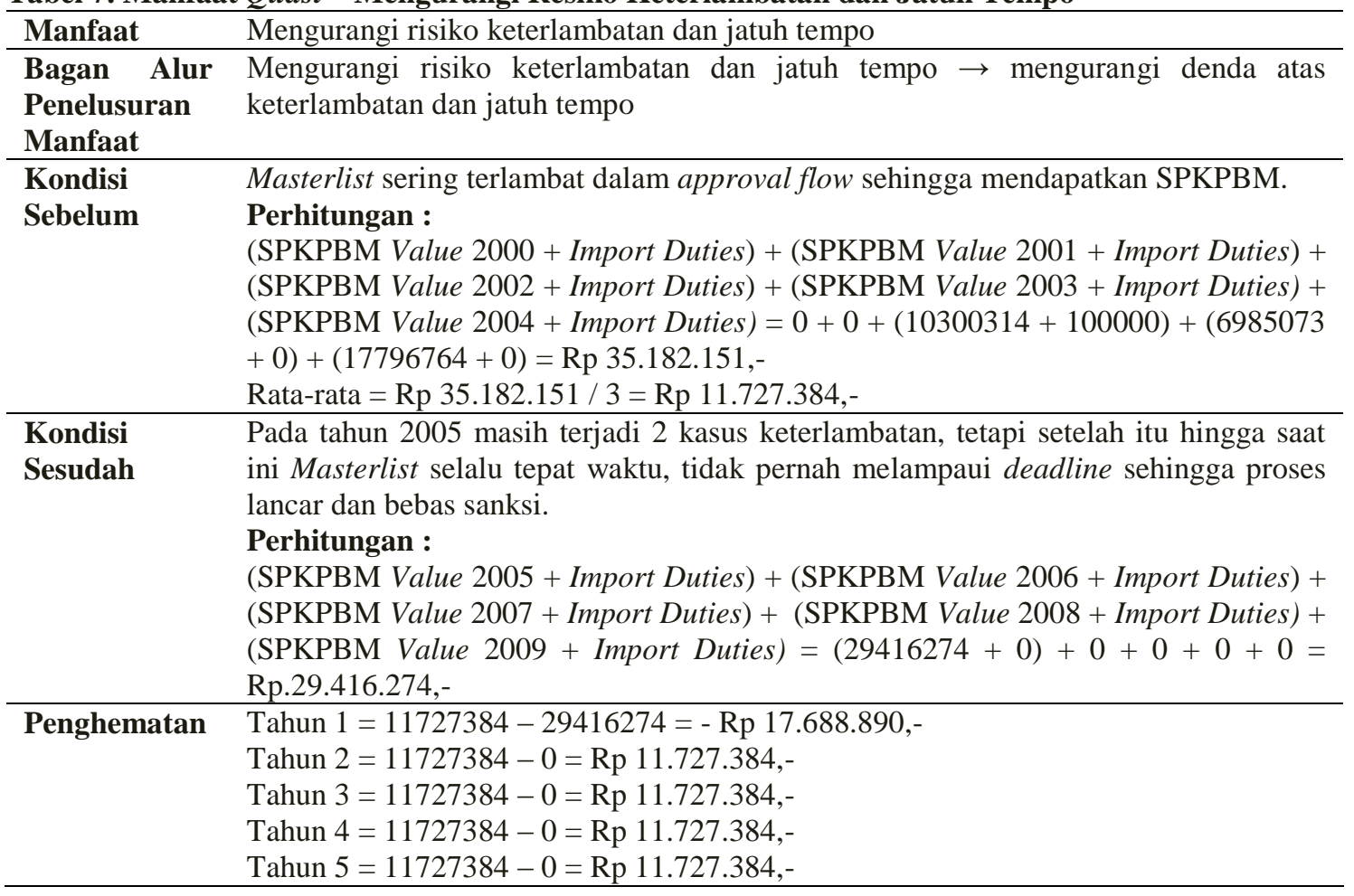

Nilai total Value Linking diperoleh dari total seluruh penghematan yang dihasilkan oleh tiap manfaat yang telah dijabarkan diatas. 


\section{Analisa Value Acceleration}

Tabel 7. Manfaat Quasi - Mempercepat Proses Impor Barang \& Custom Clearance

\begin{tabular}{ll}
\hline Manfaat & Mempercepat Proses impor barang dan Custom Clearance \\
\hline Bagan Alur & Mempercepat proses impor barang dan Custom Clearance $\rightarrow$ pengurangan durasi \\
Manfaat & dalam penanganan pekerjaan $\rightarrow$ pengurangan tenaga kerja yang menangani $\rightarrow$ \\
\hline Kondisi & Penghematan atas biaya gaji tenaga kerja \\
Sebelum & mempengaruhi keseluruhan proses hingga sumber daya manusianya. Data durasi \\
& pengerjaan dan tenaga kerja yang menangani per tahun dapat dilihat dibawah ini. \\
& Tahun $1=18$ proses dalam 180.27 hari dengan tenaga kerja sebanyak 7 orang \\
& Tahun $2=30$ proses dalam 238.52 hari dengan tenaga kerja sebanyak 9 orang \\
& Tahun $3=29$ proses dalam 87.57 hari dengan tenaga kerja sebanyak 5 orang \\
& Tahun $4=20$ proses dalam 199.12 hari dengan tenaga kerja sebanyak 6 orang \\
& Tahun $5=23$ proses dalam 147.42 hari dengan tenaga kerja sebanyak 7 orang \\
\hline Kondisi & Proses pengadaan barang bisa tepat waktu dan tidak terlampau jauh dari normal time, \\
& yaitu 71 hari. Data durasi pengerjaan dan tenaga kerja yang menangani per tahun \\
& dapat dilihat dibawah ini \\
& Tahun $1=15$ proses dalam 91.85 hari dengan tenaga kerja sebanyak 3 orang \\
& Tahun $2=15$ proses dalam 88.88 hari dengan tenaga kerja sebanyak 2 orang \\
& Tahun $3=27$ proses dalam 74.07 hari dengan tenaga kerja sebanyak 3 orang \\
& Tahun $4=21$ proses dalam 75.59 hari dengan tenaga kerja sebanyak 3 orang \\
& Tahun $5=19$ proses dalam 68.16 hari dengan tenaga kerja sebanyak 2 orang \\
\hline Asumsi biaya gaji per tenaga kerja $=$ Rp $10.000 .000,-$ \\
Total Penghematan Tahun $1=(7-3) * 120.000 .000=$ Rp $480.000 .000,-$ \\
Total Penghematan Tahun $2=(9-2) * 120.000 .000=$ Rp $840.000 .000,-$ \\
Total Penghematan Tahun $3=(5-3) * 120.000 .000=$ Rp $240.000 .000,-$ \\
Total Penghematan Tahun $4=(6-3) * 120.000 .000=$ Rp $360.000 .000,-$ \\
Total Penghematan Tahun $5=(7-2) * 120.000 .000=$ Rp $600.000 .000,-$ \\
\hline
\end{tabular}

\section{Analisa Value Restructuring}

Tabel 8. Manfaat Quasi - Meningkatkan Produktivitas

\begin{tabular}{|c|c|}
\hline Kategori & Increasing Productivity \\
\hline Manfaat & Meningkatkan produktivitas dengan restrukturisasi \\
\hline $\begin{array}{l}\text { Bagan Alur } \\
\text { Penelusuran } \\
\text { Manfaat }\end{array}$ & $\begin{array}{l}\text { meningkatkan produktivitas dengan restrukturisasi } \rightarrow \text { mengurangi biaya non } \\
\text { produktif karyawan }\end{array}$ \\
\hline $\begin{array}{l}\text { Kondisi } \\
\text { Sebelum }\end{array}$ & $\begin{array}{l}\text { Pada masa ini pekerjaan dilakukan tanpa bantuan suatu aplikasi. Setiap posisi dalam } \\
\text { departemen ini saling bekerjasama untuk turut andil dalam penyelesaian segala } \\
\text { bentuk pekerjaan yang terjadi. } \\
\text { Dari situasi seperti itu pada akhirnya menghasilkan total biaya produktif sebesar Rp } \\
\text { 898.552.500,- dan Less Productive Time sebesar Rp 55.447.500,-. }\end{array}$ \\
\hline $\begin{array}{l}\text { Kondisi } \\
\text { Sesudah }\end{array}$ & $\begin{array}{l}\text { Penggunaan ECCS mampu meningkatkan fungsionalitas masing-masing posisi dalam } \\
\text { meningkatkan kapasitas kerja karena dapat membuat pekerjaan lebih mudah } \\
\text { diselesaikan dengan efektif dan efisien. Oleh karena itu dapat membawa perubahan } \\
\text { pada produktivitas karyawan yang meningkat. } \\
\text { Dari situasi seperti itu pada akhirnya diperoleh total biaya produktif sebesar Rp } \\
\text { 929.865.000,- dan Less Productive Time sebesar Rp } 24.135 .000,- \text {. }\end{array}$ \\
\hline
\end{tabular}

Perhitungan Less Productive Time masa pre-implementasi dan pasca implementasi ECCS diperoleh dari Total gaji karyawan - Total biaya produktif. Pada masa pre implementasi diperoleh nilai Less Productive Time sebesar Rp 55.447.500,-. Sedangkan pada masa pasca implementasi diperoleh diperoleh nilai Less Productive Time sebesar Rp 24.315.000,-. Dengan demikian perkiraan besar manfat Value Restructuring yang diperoleh akibat 
pengimplementasian ECCS adalah: Total Penghematan = Total Produktivitas pasca ECCS Total Produktivitas pre-ECCS = Rp 929.865.000 - Rp 898.552.500 = Rp. 31.312.500,-

\subsection{Economic Impact Worksheet}

Economic Impact Worksheet yang dihasilkan dengan manfaat tangible dapat dilihat di tabel 9. Perolehan ROI sederhana dari manfaat Tangible adalah sebesar 98,59\%.

Tabel 9. Economic Impact Worksheet - Tangible

\begin{tabular}{|c|c|c|c|c|c|c|}
\hline $\mathrm{A}$ & & & Investa & mplementasi EC & : : 1.089.766.000 & \\
\hline B & & & Arus K & Tahunan : untuk & riode 5 tahun & \\
\hline & Tahun ke-1 & Tahun ke-2 & Tahun ke-3 & Tahun ke-4 & Tahun ke-5 & \\
\hline $\begin{array}{l}\text { Manfaat } \\
\text { Ekonomi } \\
\text { Bersih } \\
\end{array}$ & & & & & & \\
\hline $\begin{array}{l}\text { Pengurangan } \\
\text { Biaya } \\
\text { Operasional }\end{array}$ & 1.314 .887 .493 & 1.373 .720 .041 & 1.373 .720 .041 & 1.373.720.041 & 1.373 .720 .041 & \\
\hline $\begin{array}{l}\text { Pendapatan } \\
\text { Sebelum Pajak }\end{array}$ & 1.314 .887 .493 & 1.373 .720 .041 & 1.373 .720 .041 & 1.373 .720 .041 & 1.373 .720 .041 & \\
\hline Biaya Berjalan & 287.508 .000 & 287.508 .000 & 287.508 .000 & 287.508 .000 & 287.508 .000 & \\
\hline $\begin{array}{l}\text { Arus Kas } \\
\text { Bersih }\end{array}$ & 1.027.379.493 & 1.086 .212 .041 & 1.086 .212 .041 & 1.086 .212 .041 & 1.086 .212 .041 & 5.372.227.657 \\
\hline $\mathrm{C}$ & $\begin{array}{l}\text { ROI } \\
\text { Sederhana }\end{array}$ & & & & & 98,59415062 \\
\hline
\end{tabular}

Economic Impact Worksheet yang dihasilkan dengan menambah Value Linking dapat dilihat di tabel 10. Perolehan enhanced ROI dari manfaat Tangible dan manfaat Value Linking adalah sebesar $103,08 \%$.

Tabel 10. Economic Impact Worksheet - Value Linking

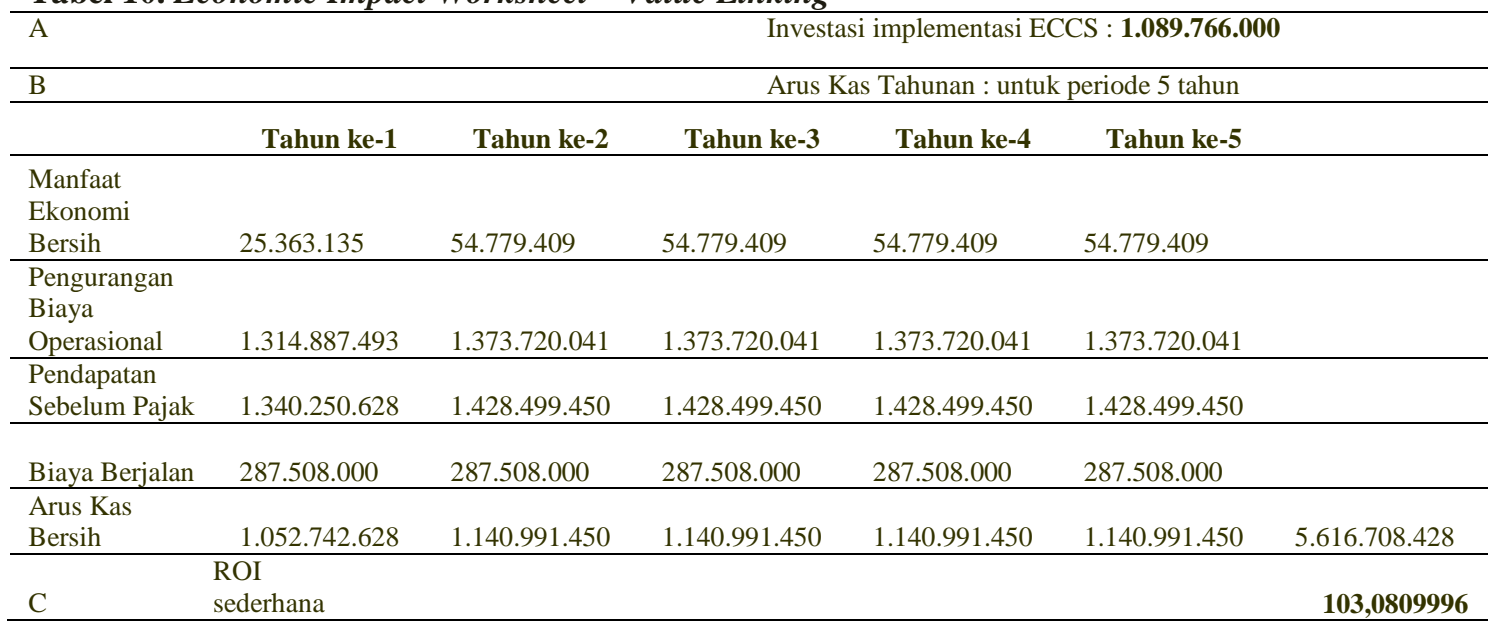

Economic Impact Worksheet yang dihasilkan dengan menambah Value Acceleration dapat dilihat di tabel 11. Perolehan enhanced ROI dari manfaat Tangible, manfaat Value Linking, dan manfaat Value Acceleration adalah sebesar 149,33\%.

Tabel 11. Economic Impact Worksheet - Value Acceleration

\begin{tabular}{|c|c|c|c|c|c|}
\hline A & & \multicolumn{4}{|c|}{ Investasi implementasi ECCS : 1.089.766.000 } \\
\hline B & & \multicolumn{4}{|c|}{ Arus Kas Tahunan : untuk periode 5 tahun } \\
\hline & Tahun ke-1 & Tahun ke-2 & Tahun ke-3 & Tahun ke-4 & Tahun ke-5 \\
\hline
\end{tabular}




\begin{tabular}{lccccc}
\hline $\begin{array}{l}\text { Manfaat } \\
\text { Ekonomi } \\
\text { Bersih }\end{array}$ & 505.363 .135 & 894.779 .409 & 294.779 .409 & 414.779 .409 & 654.779 .409 \\
\hline $\begin{array}{l}\text { Pengurangan } \\
\text { Biaya } \\
\text { Operasional }\end{array}$ & 1.314 .887 .493 & 1.373 .720 .041 & 1.373 .720 .041 & 1.373 .720 .041 & 1.373 .720 .041 \\
\hline $\begin{array}{l}\text { Pendapatan } \\
\text { Sebelum Pajak }\end{array}$ & 1.820 .250 .628 & 2.268 .499 .450 & 1.668 .499 .450 & 1.788 .499 .450 & 2.028 .499 .450 \\
\hline & & & & \\
Biaya Berjalan & 287.508 .000 & 287.508 .000 & 287.508 .000 & 287.508 .000 & 287.508 .000 \\
\hline $\begin{array}{l}\text { Arus Kas } \\
\text { Bersih }\end{array}$ & 1.532 .742 .628 & 1.980 .991 .450 & 1.380 .991 .450 & 1.500 .991 .450 & 1.740 .991 .450 \\
\hline $\begin{array}{l}\text { ROI } \\
\text { S }\end{array}$ & & & & \\
\hline
\end{tabular}

Economic Impact Worksheet yang dihasilkan dengan menambah Value Restructuring dapat dilihat di tabel 12. Perolehan enhanced ROI dari manfaat Tangible, manfaat Value Linking, manfaat Value Acceleration dan Value Restructuring adalah sebesar 152, $20 \%$.

Tabel 12. Economic Impact Worksheet - Value Restructuring

\begin{tabular}{|c|c|c|c|c|c|c|}
\hline $\mathrm{A}$ & \multicolumn{6}{|c|}{$\begin{array}{l}\text { Investasi implementasi ECCS } \\
\mathbf{1 . 0 8 9 . 7 6 6 . 0 0 0}\end{array}$} \\
\hline B & & & Arus & s Tahunan : untu & geriode 5 tahun & \\
\hline & Tahun ke-1 & Tahun ke-2 & Tahun ke-3 & Tahun ke-4 & Tahun ke-5 & \\
\hline $\begin{array}{l}\text { Manfaat } \\
\text { Ekonomi } \\
\text { Bersih } \\
\end{array}$ & 505.363 .135 & 894.779 .409 & 294.779 .409 & 414.779 .409 & 654.779 .409 & \\
\hline $\begin{array}{l}\text { Pengurangan } \\
\text { Biaya } \\
\text { Operasional }\end{array}$ & 1.346 .199 .993 & 1.405 .032 .541 & 1.405 .032 .541 & 1.405 .032 .541 & 1.405 .032 .541 & \\
\hline $\begin{array}{l}\text { Pendapatan } \\
\text { Sebelum Pajak }\end{array}$ & 1.851 .563 .128 & 2.299 .811 .950 & 1.699 .811 .950 & 1.819 .811 .950 & 2.059 .811 .950 & \\
\hline Biaya Berjalan & 287.508 .000 & 287.508 .000 & 287.508 .000 & 287.508 .000 & 287.508 .000 & \\
\hline $\begin{array}{l}\text { Arus Kas } \\
\text { Bersih }\end{array}$ & 1.564 .055 .128 & 2.012.303.950 & 1.412 .303 .950 & 1.532 .303 .950 & 1.772 .303 .950 & 8.293.270.928 \\
\hline $\mathrm{C}$ & $\begin{array}{l}\text { ROI } \\
\text { sederhana }\end{array}$ & & & & & 152,2027835 \\
\hline
\end{tabular}

\section{Kesimpulan}

Dari identifikasi dan analisa manfaat tangible dan quasi tangible aplikasi ECCS secara finansial didapatkan nilai enhanced ROI sebesar 152,20\% dimana dapat disimpulkan bahwa manfaat dari aplikasi ini telah dapat dirasakan oleh Chevron Indonesia Company Kalimantan khususnya untuk perbaikan unjuk kerja bisnis mereka.

\section{Referensi}

Parker, Marilyn M. et all. 1988. Information Economics: Linking Business Performance to Information Technology, $1^{\text {st }}$ edition. Prentice Hall, New Jersey.

Ranti, Beny. 2006. A Review of Information Technology Investment Evaluation Methodologies: The Need For Appropriate Evaluation Methods. Prosiding Konferensi Nasional TIK untuk Indonesia di ITB 3-4 Mei 2006. 